\title{
Meningkatkan Hasil Belajar Matematika Materi Penjumlahan Pecahan Penyebut Berbeda melalui Model Pembelajaran Kooperatif Tipe STAD (Student Teams Achievement Divisions) Pada Kelas Vb MIN 3 Bantul
}

\author{
Suwiatmi, S.Pd.SD \\ suwiatmiminpjg@gmail.com \\ Madrasah Ibtidaiyah Negeri 2 Bantul
}

\begin{abstract}
ABSTRAK
Pembelajaran menggunakan model STAD ini dilatarbelakangi rendahnya keaktifan dan hasil belajar siswa pada mata pelajaran Matematika dengan Pokok Bahasan Penjumlahan Pecahan Penyebut Berbeda di kelas VB MIN 3 Bantul. Hal ini disebabkan karena guru tidak menggunakan metode yang mengaktifkan siswa sehingga siswa pasif dalam proses pembelajaran. Oleh karena itu dilaksanakan pembelajaran menggunakan model STAD. Tindakan kelas dengan menggunakan model pembelajaran kooperatif tipe STAD dilaksanakan dalam 2 siklus.

Pembelajaran menggunakan model STAD ini bertujuan untuk mendapatkan data untuk menentukan efektifitas model pembelajaran kooperatif tipe STAD dalam meningkatkan prestasi dan keaktifan belajar siswa dalam pembelajaran Matematika pokok bahasan Penjumlahan Pecahan Penyebut Bebeda. Pembelajaran menggunakan model STAD ini dilaksanakan dalam 2 siklus. Setiap siklus terdiri dari 2 pertemuan. Subjek pembelajaran menggunakan model STAD adalah siswa kelas VB MIN 3 Bantul yang terdiri dari 10 siswa laki-laki dan 7 siswa perempuan. Pembelajaran menggunakan model STAD dilaksanakan pada semester I tahun ajaran 2018/2019 antara bulan Agustus sampai September 2018. Teknik pengumpulan data menggunakan lembar observasi dan lembar tes selama tindakan dan dokumentasi pelaksanaan.

Hasil pembelajaran menggunakan model STAD pada siklus I menunjukkan keaktifan dan prestasi belajar belajar mengalami peningkatan walaupun masih kecil skalanya. Dari 17 siswa 11 siswa tuntas belajar dan 6 siswa belum tuntas belajar. Pada siklus II prestasi belajar mengalami peningkatan yang signifikan, dari 17 siswa 17 siswa tuntas belajar. Berdasarkan hasil temuan, analisis data dan pengolahan data yang diperoleh dari nilai evaluasi setiap siklus dalam pelaksanaan pembelajaran menggunakan model STAD ini, maka dapat digunakan sebagai acuan bahwa penggunaan model pembelajaran kooperatif tipe proses pembelajaran dapat meningkatkan prestasi hasil belajar siswa dalam pembelajaran Matematika dengan pokok bahasan Penjumlahan Pecahan Penyebut Berbeda di kelas VB MIN 3 Bantul.
\end{abstract}

Kata kunci: keaktifan, prestasi belajar, pembelajaran kooperatif tipe STAD

\begin{abstract}
Learning using the STAD model is motivated by the low activity and student learning outcomes in mathematics with the subject of the addition of the fraction of the denominator of Bebeda in class VB MIN 3 Bantul. This is the cause because teachers do not use methods that activate students so students can participate in the learning process. Therefore learning is carried out using the STAD model. The class action using the STAD type cooperative learning model is carried out in 2 cycles.
\end{abstract}


Learning using the STAD model aims to obtain data to determine the effectiveness of the type of STAD cooperative learning model in improving learning achievement and student learning activeness in learning mathematics. Learning using the STAD model is carried out in 2 cycles. Each cycle consists of 2 meetings. The subject of learning using the STAD model is students in class VB MIN 3 Bantul consisting of 10 male students and 7 female students. Learning using the STAD model was carried out in the first semester of the 2018/2019 school year between August and September 2018. The data collection technique used observation sheets and test sheets during action and implementation.

The learning outcomes using the STAD model in the first cycle show that the activity and learning achievement increase is still small in scale. Out of 17 students, 11 students completed their studies and 6 students did not complete their studies. In the second cycle learning achievement increased significantly, from 17 students 17 students completed study. Based on the findings, data analysis and data processing obtained from the evaluation evaluation of each cycle in learning using this STAD model, it can be used as a reference regarding the use of STAD type cooperative learning models in the learning process can improve student learning outcomes in learning Addition of Denominators to Verbal Classes in class VB MIN 3 Bantul.

Keywords: activeness, learning achievement, STAD type cooperative learning.

\section{PENDAHULUAN}

Mata pelajaran Matematika mempunyai peran yang sangat penting dalam kehidupan manusia, bahkan masa depan suatu bangsa. Tetapi kenyataan yang ada di lapangan menunjukkan bahwa hasil belajar Matematika selalu berada di tingkat bawah dibandingkan dengan mata pelajaran lainnya.

Berdasarkan hasil ulangan harian matematika siswa kelas VB MIN 3 Bantul pada materi Penjumlahan Pecahan Penyebut Berbeda menunjukkan hasil yang masih relatif rendah. Data hasil nilai ulangan harian masih belum mencapai hasil yang memuaskan karena masih ada sebagian siswa yang mempunyai nilai di bawah Kriteria Ketuntasan Minimal (KKM). KKM untuk mata pelajaran Matematika di kelas VB MIN 3 Bantul adalah 70.

Hal tersebut dapat dilihat dari hasil ulangan harian Matematika 17 siswa pada materi Penjumlahan Pecahan Berpenyebut Berbeda hanya mencapai rerata 44,58 dan hanya 6 siswa $(35,29 \%)$ mencapai nilai $\geq 70$ . Padahal idealnya minimal harus mencapai $100 \%$ siswa mendapat nilai $\geq 70$. Data ini menunjukkan bahwa pembelajaran matematika merupakan mata pelajaran yang sulit dipahami
siswa.Sehingga perlu adanya upaya untuk meningkatkan hasil belajar siswa agar nilai yang dihasilkan oleh siswa dapat mencapai bahkan melebihi nilai KKM yang telah ditentukan oleh sekolah.

Perolehan nilai di bawah KKM menunjukkan bahwa pembelajaran di kelas belum mencapai hasil yang optimal.Dari hasil wawancara yang dilakukan peneliti pada siswa kelas VB MIN 3 Bantuldapat disimpulkan pelajaran Matematika dianggap sebagai pelajaran yang sulit sehingga siswa cenderung pasif dalam mengikuti kegiatan pembelajaran. Rendahnya keaktifan siswa dapat dilihat dari kurangnya respon siswa terhadap stimulus yang diberikan guru seperti jarang bertanya ataupun enggan menjawab pertanyaan dari guru dan cenderung ramai sendiri waktu dijelaskan tentang materi Penjumlahan Pecahan Berpenyebut Berbeda.

Salah satu cara untuk membangkitkan aktivitas siswa dalam proses pembelajaran adalah dengan mengganti cara/model pembelajaran konvensional yang kurang disukai oleh siswa yaitu pembelajaran yang dilakukan dengan metode ceramah dan tanya-jawab, karena model pembelajaran ini membuat siswa jenuh 
dan tidak kreatif. Guru harus mengupayakan adanya situasi dan kondisi yang menyenangkan bagi siswa dalam pembelajaran Matematika. Pembelajaran kooperatif menjadi pilihan peneliti untuk dikembangkan dalam proses pembelajaran di kelas. Pembelajaran kooperatif tipe STAD dipilih karena dengan pembelajaran kooperatif tipe STAD siswa menjadi aktif dan diharapkan prestasi belajar Matematika siswa meningkat.

Adapun tujuan pembelajaran menggunakan model STAD ini yaitu untuk mengetahui peningkatan keaktifan belajar Matematika pada materi penjumlahan pecahan penyebut berbeda pada siswa kelas VB MIN 3 Bantul Yogyakarta melalui penerapan pembelajaran kooperatif tipe STAD dan untuk mengetahui hasil belajar Matematika pada materi penjumlahan pecahan penyebut berbeda pada siswa kelas VB MIN 3 Bantul melalui penerapan pembelajaran kooperatif tipe STAD.

Student Teams Achievement Divisions (STAD) adalah metode pembelajaran kooperatif di mana para siswa dibagi ke dalam kelompok kecil yang heterogen tingkat kemampuan, jenis kelamin, serta etniknya. Selanjutnya guru menyampaikan materi pembelajaran, lalu siswa bekerja dalam kelompok untuk memastikan semua anggota kelompoknya dapat menguasai materi pelajaran. Dalam hal ini semua siswa harus saling membantu teman satu kelompoknya yang belum dapat secara baik memahami materi pembelajaran. Atau lebih khususnya, siswa harus saling membantu menyiapkan masingmasing anggota kelompoknya untuk siap menghadapi kuis individu yang nantinya akan diselenggarakan. Setelah siswa bekerja secara kelompok, maka semua siswa mengerjakan kuis mengenai materi secara individual. Dalam hal ini siswa sudah tidak dipebolehkan lagi untuk membantu teman dalam kelompoknya. Masingmasing siswa harus berusaha memberikan yang terbaik bagi kelompoknya melalui skor yang diperoleh dari penyelesaian kuis individu. Skor kuis para siswa dibandingkan dengan dengan rata-rata pencapaian mereka sebelumya, dan kepada masing-masing tim akan diberikan poin berdasarkan tingkat kemajuan yang diraih siswa dibandingkan dengan hasil yang dicapai sebelumnya. Poin ini kemudian dijumlahkan untuk memperoleh skor tim. Kelompok yang memenuhi kriteria tertentu akan mendapatkan sertifikat atau penghargaan lainnya

Menurut Slavin STAD merupakan salah satu metode pembelajaran kooperatif yang paling sederhana, dan merupakan model yang paling baik untuk permulaan bagi para guru yang baru menggunakan pendekatan kooperatif ${ }^{1}$.

Dalam pembelajaran kooperatif tipe STAD guru memberikan kesempatan kepada siswa untuk mengeluarkan pendapatnya sendiri, tampil lebih berani untuk berbicata, mendengar dan menghargai pendapat temannya, dan bersama-sama membahas permasalahan atau tugas yang diberikan guru. Dalam pembelajaran kooperatif tipe STAD terjadi pembelajaran tutor sebaya dalam kelompok-kelompok diskusi. Siswa juga dituntut untuk terus berinteraksi satu sama lain. Hal semacam ini tidak dapat ditemui dalam pembelajaran konvensional yang selama ini diterapkan.

Gagasan utama dari STAD adalah untuk memotivasi siswa supaya dapat saling mendukung satu sama lain dalam menguasai kemampuan yang diajarkan oleh guru ${ }^{2}$. Dengan demikian, materi pembelajaran tidak hanya disampaikan oleh guru, namun juga siswa dalam kelompok masing-masing. Hal ini akan menguatkan penguasaan materi bagi siswa yang kesulitan menerima penjelasan dari guru. Karena ada kemungkinan siswa tersebut lebih mudah menerima penjelasan yang disampaikan oleh temannya sendiri melalui kegiatan belajar kelompok.

Menurut Slavin menyatakan bahwa, STAD terdiri atas lima komponen utama yaitu : presentasi kelas, tim, kuis, skor kemajuan individual dan rekognisi tim ${ }^{3}$.

${ }^{1}$ Robert E. Slavin, Cooperative Learning: Teori, Riset dan Praktik, terjemahan Narulita Yusron, (Bandung: Nusa Media, 2009), 143

${ }^{2}$ Ibid, 12

${ }^{3}$ Ibid, 143 
Presentasi kelas. Materi pertama-tama diperkenalkan dalam presentasi diperkenalkan di dalam kelas oleh guru. Dalam presentasi haruslah benar-benar berfokus pada STAD. Kelompok atau tim terdiri dari empat atau lima siswa yang berbeda tingkat kemampuan, jenis kelamin, dan ras (suku). Siswa bekerja dengan kelompok terhadap tugas yang diberikan dengan cara didiskusikan bersama anggota kelompoknya. Bila siswa merasa kesulitan maka siswa yang mampu harus membantu kesulitan teman sekelompoknya, jika kelompok taidak dapat mengatasinya maka perlu meminta bantuan guru.

Kuis. Pelaksanaan kuis berlangsung setelah satu atau dua periode penyampaian materi dan kerja kelompok. Selama kuis setiap siswa harus mengerjakan sendiri dan tidak boleh bekerja sama dengan siswa lain meskipun dengan teman kelompoknya. Berdasarkan hal itu siswa bertanggungjawab terhadap dirinya sendiri.

Skor kemajuan individual. Tujuan adanya skor kemajuan individual adalah untuk memberikan hasil akhir yang maksimal pada setiap peserta didik. Hal ini akan dapat diperoleh kalau siswa lebih keras dalam melaksanakan kuis.

Menurut Sugiyanto (2009:44) menyatakan bahwa, "Para guru menggunakan metode STAD untuk mengajarkan informasi akademik baru kepada siswa". Dalam metode STAD terdapat beberapa langkah - langkah sebagai berikut

Langkah pertama adalah memperkenalkan materi dalam presentasi di dalam kelas, baik itu materi yang dibuat sendiri maupun materi yang diadaptasikan dari buku teks atau sumbersumber terbitan lainnya.

Langkah kedua dalam STAD adalah membagi siswa ke dalam Tim atau kelompok, masing-masing terdiri empat atau lima anggota kelompok. Diusahakan tiap tim memiliki anggota yang heterogen baik jenis kelamin, ras,etnik mapun kemampuan. Bila perlu dibuat terlebih dahulu daftar siswa berdasarkan kemampuannya sehingga mudah dalam membaginya ke dalam tim.
Langkah ketiga tiap anggota tim menggunakan lembar kerja akademik dan kemudian saling membantu untuk menguasai bahan ajar melalui tanya jawab atau diskusi antar sesama anggota tim. Selanjutnya secara individual atau tim dievaluasi untuk mengetahui penguasaan mereka terhadap bahan akademik yang telah dipelajari,

Langkah keempat tiap siswa dan tiap kelompok diberi skor sesuai penguasaannya terhadap bahan ajar. Kemudian kepada siswa atau kelompok yang meraih prestasi tinggi diberi penghargaan.Bila perlu beberapa atau semua tim memperoleh penghargaan jika mampu meraih suatu kriteria atau standar tertentu.

Manfaat dari pembelajaran menggunakan model STAD ini adalah: (1) Siswa: agar mendapatkan pengalaman belajar yang lebih menarik, menyenangkan, dan mengasyikkan dan mampu meningkatkan kualitas prestasi belajar serta meningkatkan keaktifan dan motivasi siswa dalam proses pembelajaran khususnya pembelajaran matematika. (2) Guru: agar dapat menambah wawasan dan informasi tentang pilihan berbagai bentuk- bentuk strategi pembelajaran, khususnya pembelajaran Matematika. (3) Sekolah: diharapkan dapat memberikan informasi dalam peningkatan kualitas pendidikan.

Berdasarkan landasan teori yang telah dikemukakan, Pembelajaran menggunakan model STAD pada kelas 5B MIN 3 Bantul sangat penting untuk dilaksanakan dengan hepotesis bahwa penerapan model pembelajaran kooperatif tipe STAD dapat meningkatkan hasil belajar Matematika pada materi Penjumlan Pecahan Penyebut Berbeda di Kelas VB MIN 3 Bantul.

\section{METODE PENELITIAN}

Penelitian Tindakan Kelas yang dilaksanakan di kelas VB MIN 3 Bantul pada mata pelajaran Matematika dengan materi Penjumlahan pecahan penyebut berbeda mulai tanggal 29 Agustus-8 September 2018.. Jumlah siswa kelas VB sebanyak 17 siswa terdiri dari 10 
siswa laki-laki dan 7 siswa perempuan. Lokasi MIN 3 Bantul berada di Waung, Guwosari, Pajangan, Bantul, Yogyakarta.

Penelitian dilaksanakan dalam 2 siklus, setiap siklus terdiri dari (1) perencanaan , (2) pelaksanaan, (3) pengamatan, dan (4) refleksi.

Perencanaan meliputi (1) Membuat rencana pelaksanaan pembelajaran (RPP) tentang materi yang akan diajarkan sesuai dengan pembelajaran matematika menggunakan model pembelajaran kooperatif tipe STAD. RPP ini berguna sebagai pedoman guru dalam melaksanakan kegiatan pembelajaran di kelas. RPP disusun sesuai dengan standar kompetensi yang ada dalam silabus dan dikembangkan dengan mengacu pada langkah- langkah pembelajaran kooperatif tipe STAD. (2) Menyusun dan mempersiapkan lembar observasi mengenai partisipasi siswa dalam kegiatan pembelajarankooperatif tipe STAD. (3) Mempersiapkan sarana dan media pembelajaran yang akan digunakan dalam setiap pembelajaran yaitu lembar kerja siswa (LKS). (4) Membuat kelompok kerja dalam kelas yang disusun berdasarkan keragaman individu.(5) Mempersiapkan soal tes untuk siswa yaitu tes yang akan diberikan pada awal siklus dan tes yang diberikan pada akhir siklus. Tes hasil belajar berbentuk isian singkat untuk mengukur hasil belajar siswa pada materi Penjumlahan Pecahan Berpenyebut Tidak Sama secara individu. Sedangkan soal kelompok dalam proses pembelajaran kooperatif terbagi dalam dua yaitu pada pertemuan 1 dan pertemuan 2 .

Pelaksanaan Tindakan dilakukan dengan menggunakan panduan perencanaan yang telah dibuat dan dalam pelaksanaannya bersifat fleksibel dan terbuka terhadap perubahanperubahan selama proses pembelajaran berlangsung, guru mengajar siswa dengan menggunakan RPP yang telah dibuat. Sedangkan peneliti yang dibantu observer mengamati partisipasi siswa pada saat proses pembelajaran di kelas.

Observasi/pengamatan di laksanakan selama proses pembelajaran di kelas berlangsung dengan menggunakan lembar observasi yang telah dibuat. Observasi dilakukan untuk melihat secara langsung bagaimana partisipasi siswa pada saat proses pembelajaran berlangsung.

Refleksi berupa diskusi antara peneliti dan asesor untuk menganalisis data yang diperoleh pada lembar observasi. Diskusi tersebut bertujuan untuk mengetahui hasil tindakan yang telah dilakukan yaitu dengan cara melakukan penilaian terhadap proses yang terjadi, masalah yang muncul dan segala hal yang berkaitan dengan tindakan yang dilakukan. Setelah itu mencari jalan keluar terhadap masalah-masalah yang mungkin timbul agar dapat dibuat rencana perbaikan pada siklus II.

Siklus dalam penelitian tindakan kelas berakhir apabila sasaran pembelajaran menggunakan model STAD sudah tercapai yaitu $75 \%$ siswa mendapatkan nilai di atas 70 .

Teknik yang digunakan untuk mengumpulkan data tentang keaktifan berupa observasi yang dilakukan oleh observer pada saat perbaikan pembelajaran dilaksanakan pada setiap siklus. Sedangkan data tentang hasil belajar siswa diperoleh melalui pemberian evaluasi secara tertulis dan lisan.

Pelaksanaan penelitian dari siklus pertama dan kedua dibantu oleh seorang observer yang bertugas melakukan pengamatan (Observasi) dan mencatat segala peristiwa pembelajaran yang berlangsung. Observer juga membantu dan bekerjasama dengan peneliti dalam mengumpulkan data, berdiskusi untuk memberikan saran terhadap kekurangan maupun guna tercapainya perbaikan yang diharapkan.

Observasi di laksanakan selama proses pembelajaran di kelas berlangsung dengan menggunakan lembar observasi yang telah dibuat. Observasi dilakukan untuk melihat secara langsung bagaimana partisipasi siswa pada saat proses pembelajaran berlangsung. Sedangkan evaluasi hasil belajar dilaksanakan sebelum dan sesudah pembelajaran dengan menggunakan lembar soal evaluasi.

Teknik analisis data pada pembelajaran menggunakan model STAD tindakan kelas ini dilakukan secara deskriptif kuantitatif. Data yang dianalisis secara kuantitatif adalah hasil 
tes evaluasitentang penjumlahan pecahan berpenyebut tidak sama pada setiap siklus. Data tersebut mengukur pencapaian hasil belajar siswa.

Data hasil tes siswa disajikan dalam bentuk data tunggal.Dari data tersebut ditentukan :

1. Prosentase nilai siswa

2. Mean (rata-rata kelas) dengan rumus :

$$
\text { Mean }=\frac{\sum_{\mathrm{i}=1}^{\mathrm{n}} \mathrm{f}_{\mathrm{i}} \mathrm{x}_{\mathrm{i}}}{\sum \mathrm{f}}
$$

Berdasarkan data yang diperoleh dapat diketahui persentase siswa yang memenuhi KKM. KKM untuk mata pelajaran Matematika di MIN 3 Bantul tahun ajaran 2018/2019 adalah 70 .

Sedangkan situasi pembelajaran saat dikenai tindakan diamati dengan menggunakan lembar observasi berupa lembar checklist

Penelitian Tindakan Kelas ini dinyatakan berhasil jika keaktifan siswa sudah meningkat menjadi $75 \%$ dan hasil belajar mencapai $75 \%$ dari jumlah siswa pada mata pelajaran Matematika materi penjumlahan pecahan berpenyebut tidak sama di kelas VB MIN 3 Bantul tahun ajaran 2018/2019 mencapai nilai di atas KKM.

\section{HASIL DAN PEMBAHASAN}

Penelitian Tindakan Kelas yang dilaksanakan pada siswa kelas VB MIN 3 Bantul yang berjumlah 17 siswa terdiri dari 10 orang laki-laki dan 7 orang perempuan.

Penelitian Tindakan Kelas ini dilaksanakan sesuai dengan rencana mulai 29 Agustus-8 September 2018, diawali dengan perencanaan dari tanggal 20 Agustus 2018 sampai dengan 27 Agustus 2018. Pelaksanaan pembelajaran menggunakan model STAD terdiri dari 2 (dua) siklus.Setiap siklus terdiri dari dua kali pertemuan.

\section{Siklus I}

Siklus pertama dilaksanakan dua kali pertemuan. Pertemuan pertama dilaksanakan tanggal 29 Agustus 2018, dengan Kompetensi Dasar Penjumlahan Pecahan Penyebut Berbeda. Pertemuan kedua dilaksanakan tanggal 1 September 2018 dengan Kompetensi Dasar Penjumlahan Pecahan Berpenyebut Berbeda. Pembelajaran berlangsung dengan lebih baik, daripada pembelajaran yang tidak menggunakan perlakuan yaitu dengan menggunakan model pembelajaran kooperatif tipe STAD, salah satu indikasinya terjadi peningkatan antusiasme siswa dan peningkatan hasil belajar siswa.

Pada siklus I ini tahap perencanaan dimulai dengan membuat rencana pelaksanaan pembelajaran untuk siklus I, membuat soal pre tes untuk mengetahui kemampuan awal siswa, membuat kuis dan lembar kerja siswa, kemudian pembentukan kelompok siswa berdasarkan pada kemampuan siswa dan jenis kelamin. Penentuan kemampuan siswa diperoleh dari nilai ulangan Matematika pada pembelajaran sebelumnya. Berdasarkan jumlah siswa kelas VBMIN 3 Bantul 2018 yaitu 17 siswa maka dibentuk lima kelompok dengan jumlah anggota tiga dan empat siswa.

Tahap Pelaksanaan, pertemuan pertama dilaksanakan pada tanggal 29 Agustus 2018. Materi yang diajarkan adalah Penjumlahan Pecahan Penyebut Berbeda. Guru memotivasi siswa dan menginformasikan cara belajar yang akan ditempuh dengan pembelajaran kooperatif tipe (STAD). Dengan tanya jawab, guru mengecek materi sebelumnya yaitu materi Penjumlahan Pecahan. Siswa mendengarkan penjelasan guru tentang Penjumlahan Pecahan Penyebut Berbeda. Beberapa siswa maju ke depan untuk mengerjakan soal tentang Penjumlahan Pecahan Berpenyebut Berbeda.

Siswa mengerjakan soal individual yang digunakan untuk menetapkan skor awal.Skor awal digunakan sebagai acuan dalam menilai kemajuan belajar siswa selama pembelajaran kooperatif tipe STAD dilaksanakan. Setelah itu, siswa dikelompokkan berdasarkan kemampuan belajarnya.Setiap kelompok terdiri dari 4 siswa, siswa mengerjakan soal secara berkelompok. Selama diskusi kelompok, guru berkeliling memberikan bimbingan kepada kelompok yang 
mengalami kesulitan dalam menyelesaikan tugas. Kemudian, siswa dengan bimbingan guru membahas hasil kerja kelompok. Guru memberikan penilaian terhadap hasil kerja kelompok siswa. Kegiatan akhir, siswa dengan bimbingan guru membuat rangkuman pembelajaran pada pertemuan ini.

Pertemuan kedua dilaksanakan pada tanggal 1 September 2018. Materi yang diajarkan adalah Penjumlahan Pecahan Penyebut Berbeda. Guru mengadakan tanya jawab tentang pembelajaran sebelumnya yaitu materi penjumlahan pecahan penyebut Berbeda. Siswa mendengarkan penjelasan penyampaian tujuan pembelajaran dari guru.

Siswa mendengarkan penjelasan guru tentang materi Penjumlahan Pecahan Penyebut Berbeda. Beberapa siswa maju ke depan untuk melengkapi kelipatan suatu bilangan dari contoh soal yang diberikan oleh guru. Kemudian, siswa mengerjakan tugas diskusi kelompok Selama diskusi kelompok, guru berkeliling memberikan bimbingan kepada kelompok yang mengalami kesulitan dalam menyelesaikan tugas. Setelah itu, siswa dengan bimbingan guru membahas hasil kerja kelompok. Pembahasan hasil kerja siswa dilakukan agar siswa mengetahui keberhasilan kelompoknya dalam menyelesaikan tugas.Siswa mengerjakan tugas individual (kuis individual). Kuis diberikan agar dapat mengetahui tingkat pemahamaman siswa setelah pembelajaran kooperatif tipe STAD dilaksanakan.Hasil dari kuis individual dijadikan dasar dalam penentuan poin kemajuan kelompok.Dalam pengerjaan kuis individual siswa mengerjakan secara mandiri dan tidak boleh saling membantu antar teman dalam satu kelompok.

Guru melakukan penilaian terhadap hasil kerja siswa. Setelah dilakukan penilaian terhadap nilai kuis siswa maka dilakukan evaluasi terhadap predikat kelompok.Predikat kelompok ditentukan berdasarkan rata - rata poin kemajuan tiap kelompok.

Pada tahap Observasi dan Evaluasi, Observasi dilakukan terhadap pelaksanaan pembelajaran kooperatif tipe STAD di kelas oleh kolabolator pada saat pembelajaran berlangsung. Pengamatan dilakukan terhadap tiap kelompok dan pembelajaran secara klasikal dalam kelas. Hasil observasi pada siklus I menunjukkan bahwa masih terdapat kelompok yang kurang kompak dalam mengerjakan tugas kelompok. Penggunaan waktu oleh kelompok dalam menyelesaikan tugas masih belum maksimal, ada dua kelompok yang terlambat mengerjakan tugas dari waktu yang telah ditentukan.

\section{Siklus II}

Pada perencanaan siklus II rancangan tindakan berdasarkan pada hasil refleksi siklus pertama. Pemberian soal kepada siswa pada tes awal tidak terlalu banyak sehingga siswa tidak kekurangan waktu dalam mengerjakan soal evaluasi.

Pertemuan pertama dilaksanakan pada tanggal 5 September 2018. Materi yang diajarkan adalah Penjumlahan Pecahan Berpenyebut Berbeda. Siswa mendengarkan penjelasan guru mengenai tujuan pembelajaran pada pertemuan kali ini yaitu dapat menentukan hasil dari Penjumlahan Pecahan Penyebut Berbeda. Kemudian siswa mendapatkan motivasi dari guru untuk lebih bersungguh-sungguh dalam mengikuti pembelajaran kooperatif tipe STAD. Setiap anggota kelompok saling membantu dalam mengerjakan tugas kelompok. Predikat kelompok diperoleh dari nilai siswa secara individu. Siswa yang pandai memberikan bimbingan kepada siswa yang kurang pandai sehingga nilai semua anggota dapat mencapai nilai kemajuan yang memuaskan. Siswa mendengarkan keterangan guru mengenai nilai siswa yang masih rendah. Guru memberikan keterangan mengenai predikat kelompok yang telah diraih siswa agar mereka lebih termotivasi untuk giat belajar.

Setelah itu, dilanjutkan dengan tanya jawab tentang pemahaman siswa terhadap materi Penjumlahan Pecahan Berpenyebut Berbeda. Siswa mendengarkan penjelasan guru tentang materi pembelajaran Penjumlahan Pecahan Penyebut Berbeda.Kemudian, siswa mengerjakan tugas individu sebelum tugas 
berkelompok. Siswa mengerjakan tugas dengan diskusi dalam kelompok.Pengelompokan siswa masih berdasarkan pada pembagian pada siklus I. Siswa yang mengalami kesulitan bertanya kepada guru. Guru memberikan bimbingan yang lebih terhadap siswa yang masih kesulitan dalam kelompok. Siswa mengerjakan tugas individual.Kemudian, siswa dan guru membahas tugas individual. Guru memberikan penilaian terhadap tugas yang telah dikerjakan

Pertemuan kedua dilaksanakan pada tanggal 8 September 2018. Materi yang diajarkan adalah Penjumlahan Pecahan Penyebut Berbeda. Siswa mendengarkan penjelasan guru tentang tujuan pembelajaran pada hari ini yaitu siswa dapat menentukan hasil Penjumlahan Pecahan Penyebut Berbeda. Siswa mendengarkan penjelasan guru tentang cara memecahkan masalah yang berkaitan Penjumlahan Pecahan Berpenyebut Berbeda .Siswa dengan bimbingan guru mengerjakan soal yang berkaitan dengan Penjumlahan Pecahan Penyebut Berbeda. Siswa mengerjakan tugas individual. Tugas individual ini dilaksanakan sebagai dasar untuk mengetahui peningkatan hasil belajar siswa sebelum dan sesudah pembelajaran kooperatif tipe STAD dalam materi yang sama. Siswa berkelompok sesuai dengan kelompok sebelumnya untuk mengerjakan soal.Kelompok siswa yang mengalami kesulitan mendapatkan bimbingan dari guru. Siswa bersama dengan guru membahas soal kelompok.

Setelah pembahasan soal kelompok, siswa mengerjakan kuis individual. Kuis individual dilaksanakan oleh setiap siswa dan anggota kelompok yang lain tidak boleh memberikan bantuan. Kemudian diadakan penilaian dan tindak lanjut pada hasil kuis individual dan dilanjutkan menentukan predikat kelompok. Penentuan predikat kelompok dilaksanakan dengan mencari rata - rata nilai kemajuan yang diperoleh masing - masing anggota kelompok. Nilai rata - rata tersebut yang digunakan dalam menentukan kriteria/predikat kelompok.

Tahap Observasi dan Evaluasi Berdasarkan hasil obeservasi terdapat peningkatan kerja sama antar siswa dalam satu kelompok. Siswa lebih tekun mengerjakan tugas dan tidak ada anggota kelompok yang masih acuh tak acuh saat mengerjakan tugas kelompok.Tiap anggota kelompok menyadari bahwa mereka memberikan andil dalam penentuan predikat kelompok pada akhir pembelajaran. Setiap anggota kelompok mempunyai peran yang sama dalam kelompoknya.

Pada pelaksanaan pembelajaran kooperatif tipe STAD siklus kedua terdiri dari dua nilai yaitu nilai pada tes awal dan nilai pada kuis individual diakhir pembelajaran. Nilai awal dan nilai kuis pada akhir pembelajaran wajib dilakukan sebagai dasar dalam menentukan predikat kelompok di akhir pembelajaran kooperatif.

\section{PEMBAHASAN}

Dari data yang diperoleh dapat diketahui tingkat perubahan yang terjadi terhadap hasil belajar siswa meliputi nilai data awal sebelum diadakan perbaikan, nilai Siklus I dan nilai Siklus II . Sebelum diadakan perbaikan nilai hasil belajar pada ulangan formatif dengan materi Penjumlahan Pecahan Penyebut Berbeda (data awal) diperoleh : 6 siswa $(35,29 \%)$ telah mencapai ketuntasan belajar, sedangkan 11 siswa $(64,71 \%)$ masih dibawah ketuntasan belajar.

Nilai ulangan perbaikan pembelajaran Siklus I diperoleh : 11 siswa $(64,71 \%)$ mencapai ketuntasan belajar dan 6 siswa $(35,29 \%)$ belum tuntas belajar. Pada siklus II : 17 siswa (100\%) mencapai ketuntasan belajar.

Grafik tingkat perubahan yang terjadi dalam mencapai ketuntasan belajar siswa kelas VB MIN 3 Bantul Mata Pelajaran Matematika dengan pokok bahasan Penjumlahan Pecahan Penyebut Berbeda dapat ditunjukkan pada gambar 1.

Berdasarkan hasil penelitian yang dilaksanakan pada siklus I dan siklus II dapat dilihat peningkatan rata - rata hasil belajar siswa kelas VB MIN 3 Bantulpada materi Penjumlahan Pecahan Penyebut Berbeda dengan pendekatan pembelajaran kooperatif tipe STAD yang ditunjukkan pada gambar 2 . 


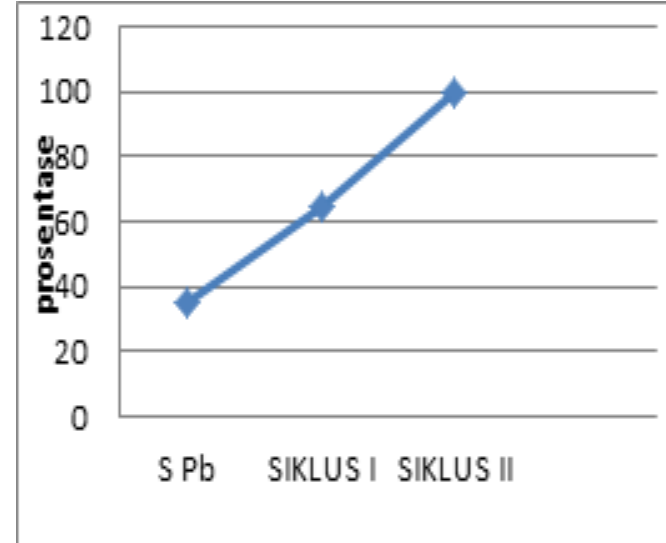

Gambar. 1

Peningkatan Ketuntasan Belajar siswa

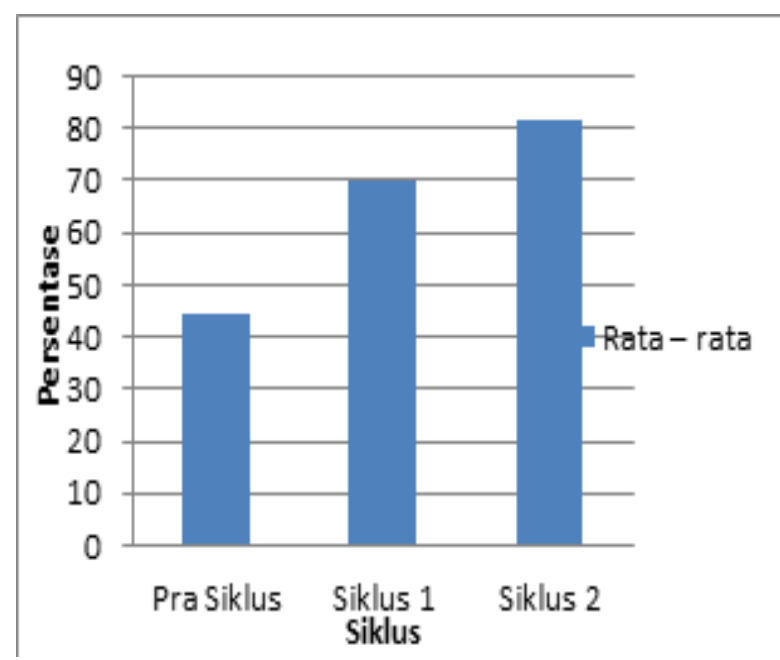

Gambar 2

Rata - Rata Hasil Belajar Siswa tiap siklus

Untuk data peningkatan ketuntasan belajar siswa kelas VB MIN 3 Bantulpada materi Penjumlahan Pecahan Penyebut Berbeda dengan pendekatan pembelajaran kooperatif tipe STAD ditunjukkan pada gambar 3

Sedangkan data keaktifan belajar siswa kelas VB MIN 3 Bantulselama pelaksanaan pembelajaran menggunakan model pembelajaran kooperatif tipe STAD ditunjukkan pada gambar 4.

Berdasarkan data tersebut maka pembelajaran kooperatif tipe STAD mampu meningkatkan prestasi siswa dan tidak diperlukan pelaksanaan siklus ketiga.Hal ini ditunjukkan dari hasil kuis individu pada siklus dua lebih baik dibandingkan pada siklus pertama.

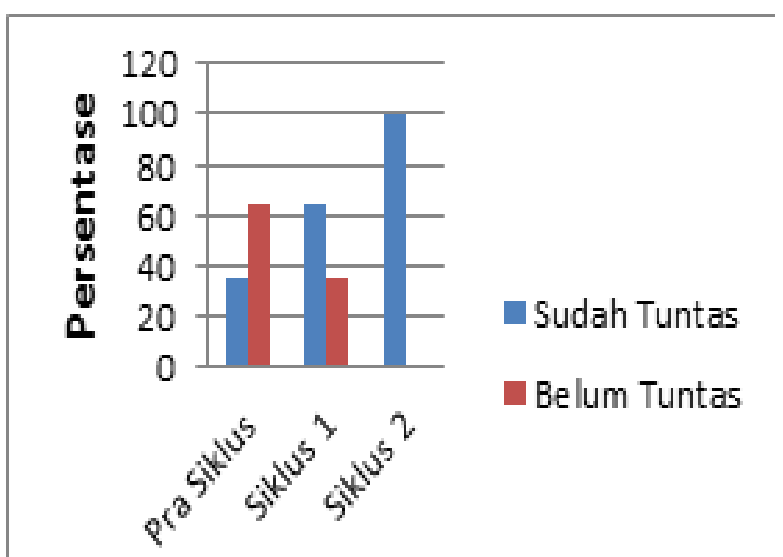

Siklus

Gambar 3.

Rekapitulasi Ketuntasan Hasil Belajar

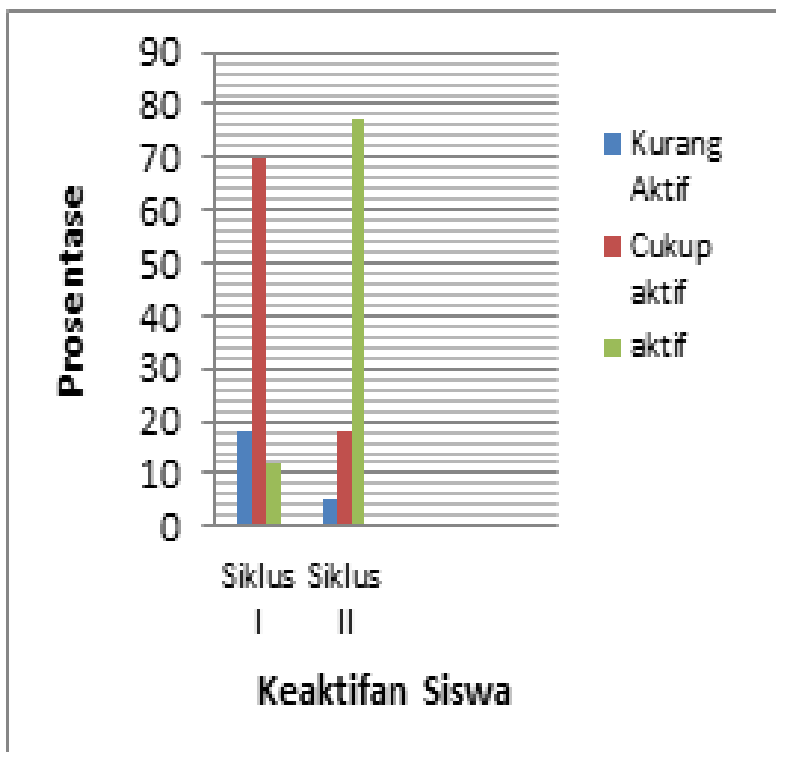

Gambar 4

Hasil Pengamatan Keaktifan Siswa

Rata - rata nilai awal siswa adalah 69,94 pada akhir siklus pertama dan meningkat lagi menjadi 81,82 pada akhir siklus kedua. Peningkatan nilai rata-rata nilai kuis ini sangat signifikan.Prestasi siswa secara keseluruhan meningkat.Prestasi ini melebihi kriteria keberhasilan yang ditetapkan yaitu 70. Hasil yang diperoleh siswa pada akhir pelaksanaan siklus 2 adalah 17 siswa atau $100 \%$ sudah memenuhi ketuntasan belajar. Berdasarkan data tersebut maka pembelajaran kooperatif tipe STAD sudah mencapai kriteria 
keberhasilan yaitu $\geq 75 \%$ siswa mendapatkan nilai $\geq 70$.

Pembelajaran kooperatif melatih siswa untuk saling bekerja sama dalam menyelesaikan tugas dan tidak hanya mementingkan prestasi individu. Pembelajaran kooperatif dapat meningkatkan motivasi belajar siswa sehingga prestasi belajar mereka pun meningkat. Dengan demikian pembelajaran yang dilakukan telah beupaya untuk menerapkan bebagai metode dan strategi pembelajaran yang sesuai dengan karakteristik peserta didik dan karakteristik materi ajar (Laelatul Badriah; 2019: 47-55), dalam hal ini terbukti dengan penggunaan pembelajran kooperatif STAD dapat meningkatkan hasil belajar matematika peserta didik kela VI MIN 3 Bantul.

\section{KESIMPULAN}

Berdasarkan hasil temuan, analisis data dan pengolahan data yang diperoleh dari nilai evaluasi setiap siklus dalam pembelajaran menggunakan model STAD ini, maka dapat disimpulkan bahwa penerapan pembelajaran kooperatif tipe STAD pada Penjumlahan Pecahan Penyebut Berbeda dapat meningkatkan hasil belajar siswa kelas VB MIN 3 Bantul Yogyakarta.

Hal ini dibuktikan dengan nilai rata-rata kelas VB MIN 3 Bantul meningkat, dari nilai pra siklus 44,58 menjadi 69,94 pada siklus I dengan rincian yang mendapat lebih dari atau sama dengan 70 ada 11 siswa $(64,70 \%)$ sedangkan yang mendapat nilai kurang dari 70 ada 6 siswa $(35,30 \%)$. Pada siklus II nilai rata-rata juga meningkat menjadi 81,82 dengan rincian yang mendapat nilai lebih dari atau sama dengan 70 ada 17 siswa (100\%) sedangkan yang mendapat nilai kurang dari 70 ada 0 siswa $(0 \%)$.

Perbaikan pembelajaran yang dilaksanakan dalam dua siklus di kelas VB MIN 3 Bantul ini, dapat digunakan sebagai acuan untuk mengatasi masalah yang terjadi dalam proses pembelajaran Matematika materi Penjumlahan Pecahan Penyebut Berbeda sehingga siswa memperoleh hasil belajar yang lebih baik sesuai dengan standar nilai yang ditentukan dalam kurikulum MIN 3 Bantul

Adapun saran yang bertujuan untuk perbaikan pada pembelajaran selanjutnya antara lain : (1) Guru lebih mengoptimalkan penggunaan alat peraga dalam pembelajaran. (2) Guru menggunakan model pembelajaran yang bervariasi dalam proses pembelajaran agar siswa termotivasi untuk belajar. (3) Siswa perlu diberikan motivasi sehingga siswa lebih berperan aktif dalam proses pembelajaran.

\section{DAFTAR PUSTAKA}

Depdiknas. 2003. Undang-Undang RI Nomor 20 Tahun 2003, Tentang sistem Pendidikan Nasional.

Erman Suhermandkk. 2001. Strategi Belajar Matematika Kontemporer, (Bandung: Tim MKPBM JICA-UPI.)

Ibrahim, Muslimin, dkk. 2002. Pembelajaran Kooperatif, (Surabaya: University Prees).

Karso dkk. 2014. Pendidikan Matematika I, (Tangerang Selatan: Universitas Terbuka)

Nana Sudjana, Ibrahim. 2010. Pembelajaran menggunakan model STAD dan Penilaian Pendidikan, (Bandung: Sinar Baru Algesindo)

Robert E. Slavin, Cooperative Learning: Teori, Riset dan Praktik, terjemahan Narulita Yusron, (Bandung: Nusa Media, 2009)

Sugiyono. 2006. Metode Pembelajaran menggunakan model STAD Pendidikan, (Bandung : Alfabeta)

Suharsimi Arikunto, 2006. Pembelajaran menggunakan model STAD Tindakan Kelas, (Jakarta : Bumi Aksara).

Sujono.2004. Pembelajaran Quantum Learning, (Bandung : Aglesindo)

Wina Sanjaya, 2008. Strategi Pembelajaran: Berorientasi Standar Proses Pendidikan, (Jakarta: Kencana)

Anonim, artikel ilmiah, http://www.hasiltesguru. com/pengertian-hasil-belajar.10/03/2015 